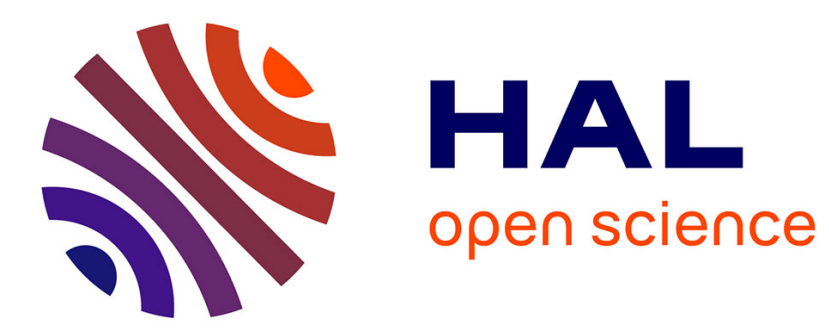

\title{
Emigration intentions of Roma: evidence from Central and South-East Europe
}

Laetitia Duval, François-Charles Wolff

\section{To cite this version:}

Laetitia Duval, François-Charles Wolff. Emigration intentions of Roma: evidence from Central and South-East Europe. 2016. hal-01280578

\section{HAL Id: hal-01280578 \\ https://hal.science/hal-01280578}

Preprint submitted on 29 Feb 2016

HAL is a multi-disciplinary open access archive for the deposit and dissemination of scientific research documents, whether they are published or not. The documents may come from teaching and research institutions in France or abroad, or from public or private research centers.
L'archive ouverte pluridisciplinaire HAL, est destinée au dépôt et à la diffusion de documents scientifiques de niveau recherche, publiés ou non, émanant des établissements d'enseignement et de recherche français ou étrangers, des laboratoires publics ou privés. 


\title{
Imperial College London
}

\section{Emigration intentions of Roma: Evidence from Central and South-East Europe}

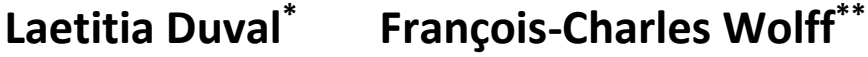

\begin{abstract}
The Roma constitute the largest, poorest and youngest ethnic minority group in Europe. Over the last few years, they have attracted unprecedented attention with the fear of massive waves of emigrants to Western European countries. Using unique comparative data from 12 Central and South-East European countries, we study the pattern and determinants of Roma emigration intentions. We find that plans to go abroad are more frequent among Roma compared to non-Roma, but the ethnic gap in emigration intentions is not explained by the more disadvantaged characteristics of Roma compared to non-Roma. Among the Roma population, potential emigrants are more educated and wealthier on average. Finally, ethnic discrimination is a very influential factor that explains the intentions to emigrate within the Roma population.
\end{abstract}

JEL classification: F22, J61, I31, J15, J13

Keywords: Emigration intention, Roma, ethnic discrimination, Central and South-East Europe

\footnotetext{
* Corresponding author. Imperial College London, School of Public Health, St Mary's Campus, Norfolk Place, London W2 1PG, United Kingdom. E-mail: I.duval@imperial.ac.uk

${ }^{* *}$ LEMNA, Université de Nantes, BP 52231 Chemin de la Censive du Tertre, 44322 Nantes Cedex, France and INED, Paris, France. E-mail: francois.wolff@univ-nantes.fr
} 


\section{Introduction}

The Roma constitute the largest, the poorest and the youngest ethnic minority group in Europe, with a population estimated at 10-12 million (Ringold et al., 2005). In recent years, the Roma have received unprecedented attention from both the media and governments, essentially concerning the fear of massive waves of emigrants to Western European countries. Curiously, the behaviour and in particular the migration decisions of this ethnic group have so far remained largely under-researched, mainly due to the lack of appropriate data. One of the reasons is the difficulty in gaining access to micro-level data: some countries do not include questions on ethnicity in their national census, or they do not recognize some ethnic groups as a legitimate category (European Commission, 2011). Another explanation is that most Roma are distrustful towards the majority population and are reluctant to reveal their ethnicity for fear of discrimination (Ringold et al., 2005; Cherkezova and Tomova, 2013).

The aim of our paper is to study the pattern of emigration intentions among Roma living in Central and South-East European countries. Specifically, we draw on an unusually rich household survey of twelve countries, conducted in 2011 by the United Nations Development Programme (UNDP), the World Bank (WB) and the European Commission (EC). The sample comprises both Roma $(N=9,207)$ and non-Roma $(N=4,274)$ households living in Albania, Bosnia and Herzegovina, Bulgaria, Croatia, the Czech Republic, Hungary, Macedonia, Moldova, Montenegro, Romania, Serbia and Slovakia. We contribute to the limited empirical economic literature on Roma by studying the profile of potential emigrants as a function of their ethnicity. We consider a comparative framework in which we contrast the emigration intentions of Roma versus non-Roma, both for the whole set of countries and for each country.

Policy makers are particularly interested in assessing the Roma's willingness to move from Central and South-East Europe, particularly within the context of the Decade of Roma Inclusion 20052015 and given that some of the countries surveyed will be part of the European Union in the near future. Information like the potential size of migration outflows, the motivations behind emigration and the location of those intending to emigrate is very useful in shaping immigration policies. To document these issues, we choose to rely on a subjective question that measures the desire to emigrate abroad in the future. Over the last decade, several studies have emphasized that intentions to emigrate were a good predictor of decisions to emigrate (Gordon and Molho, 1995; Dustmann, 2003; van Dalen et al., 2005a, 2005b; van Dalen and Henkens, 2013).

The focus on Central and South-East Europe is especially relevant for studying the emigration intentions of Roma. First, $80 \%$ of all Roma live in this region (Ringold et al., 2005). Second, these 
countries share a very similar experience of having transitioned from a communist system to a market economy during the 1990s. Some of them have also experienced intense ethnic conflicts from 1991 to 1999 in the territory of former Yugoslavia. This has led to a severe vulnerability of the population, especially for Roma people (O'Higgins, 2010; Kertesi and Kézdi, 2011a, 2011b). Third, emigration pressure remains high in these countries. According to the World Bank (2011), the current top-ranking emigrant countries as a percentage of world population are: Bosnia and Herzegovina, Albania, Macedonia and Moldova. Fourth, the living conditions of Roma have become one of the most heated issues facing Central and South-East European countries in negotiations for European Union accession.

Our empirical analysis proceeds in the following way. First, we describe the pattern of emigration intentions among Roma. We show that the proportion of potential emigrants is higher among Roma compared to non-Roma. Finding a job is the main motivation behind the intention to move abroad, both for Roma and non-Roma. We then focus on the determinants of emigration intentions and rely on a decomposition analysis. The Roma have a higher probability of intended emigration once demographic and socio-economic characteristics are taken into account, but these covariates do not really explain the ethnic gap between Roma and non-Roma. Finally, we investigate the potential role of discrimination among Roma as a push factor explaining emigration intentions. We find that discrimination based on ethnicity is the most important factor behind emigration intentions of Roma living in Central and South-East European countries.

The remainder of our study is organized as follows. In Section 2, we report the background information on Central and South-East European countries. We present the Regional Roma Survey in Section 3 and describe the pattern of emigration intentions in Section 4. In Section 5, we discuss our econometric estimates measuring the ethnic gap in intended emigration between Roma and nonRoma. In Section 6, we focus more closely on the role of discrimination as a push factor that explains Roma's emigration intentions. Section 7 provides our conclusions.

\section{Background on Central and South-East European countries}

The twelve countries under consideration in our sample are: Albania, Bosnia and Herzegovina, Bulgaria, Croatia, the Czech Republic, Hungary, Macedonia, Moldova, Montenegro, Romania, Serbia and Slovakia. These countries provide interesting settings for studying the emigration intentions of Roma. First, this is a relevant context to examine, because of the high degree of diversity between ethnic groups in Central and South-East Europe. The various countries surveyed are characterized by significant shares of Roma within their overall population. Furthermore, this proportion is expected to increase in the near future because of the high birth rates among the Roma population (Cherkezova and Tomova, 2013). 
Nevertheless, data collection on the Roma population remains challenging. For instance, the last national census in Bosnia and Herzegovina was held in 1991, and the new one is postponed due to disagreements between ethnic groups. Bosnia and Herzegovina recognizes three official ethnic groups (Bosniaks, Serbs and Croats) and excludes the others, meaning that the Roma in that country have no ethnic minority status (European Commission, 2011). Despite these difficulties, the estimates of the Council of Europe in 2010 indicate that the percentage of Roma in the total population is (by decreasing order of importance): $10.33 \%$ in Bulgaria, $9.59 \%$ in Macedonia, $9.17 \%$ in Slovakia, $8.32 \%$ in Romania, $8.18 \%$ in Serbia, $7.05 \%$ in Hungary, $3.18 \%$ in Albania, $2.95 \%$ in Montenegro, 2.49\% in Moldova, 1.96\% in the Czech Republic, 1.09\% in Bosnia and Herzegovina and $0.78 \%$ in Croatia (see Table 1$)^{1}$.

Insert Table 1

Second, the selected countries share similar experiences of political transformation and socio-economic changes since the 1990s. Following the collapse of communism, these countries have pursued strong reforms towards a market economy. However, living standards remain low in comparison with those of Western European countries. As shown in Table 1, six countries have a GDP per capita that is lower than $\$ 15,000$ (Albania, Bosnia and Herzegovina, Macedonia, Moldova, Montenegro and Serbia). According to the World Development Indicators regarding poverty, five countries are characterized by a poverty headcount ratio at national poverty line which exceeds $20 \%$ (Bulgaria, Croatia, Macedonia, Romania and Serbia). Table 1 also shows substantial heterogeneity in the unemployment rate. While it is lower than $10 \%$ in four countries (the Czech Republic, Moldova, Romania and Slovakia), it exceeds $19 \%$ in Macedonia, Bosnia and Herzegovina, Montenegro and Serbia.

Over the last two decades, this combination of low national income, high unemployment and poverty - specifically in a context marked by episodes of political instability and armed conflicts in the region - has led to significant emigration. In 2010, the stock of emigrants as a percentage of total population was above $20 \%$ in Albania, Bosnia and Herzegovina, Macedonia and Moldova (see Table 1). The proximity of attractive neighbouring countries in Western Europe has offered some opportunities. For almost every country, most of the migrants live in countries like Italy, Greece, Germany and Austria.

Third, the transition to a market economy and the ethnic conflicts in the territory of former Yugoslavia have contributed to severe declines in the living conditions of Roma in Central and SouthEast Europe when compared to other ethnic groups in these regions ( $0^{\prime} H i g g i n s, 2010$; Kertesi and Kézdi, 2011a, 2011b). On the one hand, the breakup of the communist regime in the region was

\footnotetext{
${ }^{1}$ Note that these are average proportions. In Table 1, we also provide the minimum and maximum estimates reported by the Council of Europe (http://www.coe.int/t/dg3/romatravellers/default EN.asp).
} 
accompanied by unemployment and impoverishment for the population. On the other hand, the Balkan Wars between 1991 and 1999 resulted in profound consequences marked by large numbers of victims and population displacement. Many Roma had to move as displaced persons to other neighbouring countries (Ringold et al., 2005).

Finally, the living conditions of the Roma have become an issue in negotiations surrounding the Eastern enlargement, as well as a condition for accession to the European Union (European Commission, 2011) $)^{2}$. In our sample, some countries have recently joined the European Union (Hungary, the Czech Republic and Slovakia in 2004; Romania and Bulgaria in 2007; Croatia in 2013) while others aspire to join in the near future.

\section{The UNDP/WB/EC Regional Roma Survey}

Our empirical analysis is based on the Regional Roma Survey conducted by the United Nations Development Programme, the World Bank and the European Commission from May to July 2011 in the twelve previously mentioned Central and South-East European countries. In each country, approximately 750 Roma households were interviewed as well as approximately 350 nonRoma households living in the same neighbourhoods ${ }^{3}$. The total Roma sample comprises 9,207 households and 41,334 household members. The total non-Roma sample comprises 4,274 households and 13,326 household members.

The Regional Roma Survey questionnaire consists of four modules in addition to a preliminary management section. The first module describes the profile of the various household members, which includes demographic characteristics, education, and health and employment status. The second module explores the early childhood education and care for each household member up to six years of age. The third module deals with the status of the household and includes questions concerning financial resources and living standards, among others. The fourth module concerns one randomly selected respondent within the household and covers topics such as health, values and norms, migration and discrimination ${ }^{4}$.

We investigate the pattern of emigration among the Roma population using subjective information on intentions. Specifically, we consider answers to the following question: "Would you consider moving to another country at some time in the future?". For those claiming that they intend to migrate, there are three additional questions related to intended country, expected timing and

\footnotetext{
2 The European Union accentuates the issue of ethnic minority protection and anti-discrimination in the Copenhagen criteria (European Commission, 2011).

${ }^{3}$ The number of Roma households interviewed ranges from 753 in Hungary to 788 in Macedonia.

4 For further detail, see http://www.eurasia.undp.org/content/rbec/en/home/ourwork/sustainabledevelopment/development-planning-and-inclusive-sustainable-growth/roma-in-central-and-southeasteurope/roma-data.html.
} 
their main motivations for moving: "Which country would that be?"; "Realistically, how soon would you consider moving there?" (possible answers to this question were "in less than 6 months", "in 6 to 12 months", "in more than a year", or "I will never move there"); and, finally, "What would be your reasons for moving to this particular country?" ${ }^{5}$.

Using an intended outcome (plans to go abroad) requires some comments, as such data have been the subject of heated debates. Until recently, many economists were sceptical about the empirical content of subjective data, pointing to problems concerning psychological mechanisms, interactions with the surveyor or question formulation. The situation is different nowadays, as many studies have shown that subjective questions were reliable and useful (Senik, 2005). In the migration literature, data limitations have led researchers to indirectly explore the behaviour of migrants through the use of emigration intention. Several studies argued that emigration intentions are relevant as a proxy for actual emigration. Dustmann (2003), van Dalen et al. (2005a, 2005b) and van Dalen and Henkens (2013) have shown that intentions to emigrate were a good predictor of actual realizations of the decision to emigrate. Also, the determinants of emigration intentions are quite similar compared to those explaining why people emigrate (Gordon and Molho, 1995).

In what follows, we focus on respondents aged 16 to 64 . We are left with a sample comprising 11,609 respondents: $71.4 \%$ are Roma and $28.6 \%$ are non-Roma. In Table 2, we summarize the demographic and socio-economic situation of respondents interviewed in the Regional Roma Survey. The average age of the respondents is 37.5 years, the non-Roma being older than the Roma (40.9 against 36.1 ). Also, the Roma live more frequently in a couple (71.2\%) compared to the nonRoma $(64.8 \%)$, but there is no significant difference in the proportion of women interviewed. The average number of persons in the household is around 4. This size is higher in the Roma households than in the non-Roma households (4.6 compared to 3.4).

\section{Insert Table 2}

There are large educational differences between the Roma and the non-Roma. The proportion of respondents having no formal education is $25.3 \%$ for the Roma, but it amounts to only $1.7 \%$ for the non-Roma. Conversely, only a minority of Roma has finished upper secondary education (11.8\%), while this percentage is much higher among the non-Roma (64.3\%). As a consequence of their lower levels of education, the Roma are more likely to be out of the labour market. $47.9 \%$ of the Roma respondents are not working compared to $28.2 \%$ of the non-Roma. Our measure of living standards is a wealth index derived from applying a principal component analysis on asset ownership

\footnotetext{
${ }^{5}$ Possible reasons are "better chances of finding employment", "better pay/better working conditions", "better education for children/improve own education or education", "better living conditions/social and health care system/political situation", "to join or accompany parents/family members/spouse/to get married", "less discrimination/racism", "other reason".
} 
indicators (Filmer and Pritchett, 2001) ${ }^{6}$. By construction, the average of the asset index is set to zero for the whole sample of respondents. This asset index is very unfavourable to the Roma $(-0.529)$ compared to the non-Roma (1.477).

We further explore the socio-economic differences between Roma and non-Roma by looking at potential heterogeneity between countries. We focus on education and assets, as both covariates are expected to strongly influence the emigration intentions of people living in Central and SouthEast Europe. Figure 1 reports the proportion of respondents with at least a secondary school education. It is more common to find Roma with this level of education in the Czech Republic (83.5\%), Hungary (76.0\%) and Slovakia (77.2\%). Conversely, only a minority of Roma has finished upper secondary education in Albania (26.1\%), Moldova (36.6\%) and Montenegro (26.9\%). Figure 2 shows that the asset index is unfavourable to the Roma in all countries, although the index exceeds zero for the Roma in the Czech Republic and Hungary. In terms of the asset index, the largest differences between Roma and non-Roma are observed in Croatia, the Czech Republic and Bosnia and Herzegovina.

Insert Figure 1

Insert Figure 2

\section{The pattern of emigration intentions among Roma and non-Roma}

We describe the pattern of emigration intentions in Central and South-East Europe by ethnicity in Table 3. We first focus on respondents of Roma origin (Panel A). According to the Regional Roma Survey, $25.6 \%$ of Roma respondents express their intention to emigrate to a foreign country. The situation is very different depending on countries. The desire to move abroad is higher in Serbia (43.8\%), Bosnia and Herzegovina (42.1\%) and Albania (37.5\%). Conversely, the intended emigration rate is lower than the average in Montenegro (10.6\%), Moldova (14.9\%) and Croatia (17.1\%).

Insert Table 3

When pooling all countries, the preferred destination choices for potential Roma emigrants are Germany, followed by the United Kingdom and Greece. At the country level, the intended locations highlight both the influence of migrant networks and current emigration trends from the Central and South-East European countries described in Table 1. Previous studies have shown that social networks of family and friends abroad and connection with the destination country through

\footnotetext{
${ }^{6}$ We consider the following list of items that a household can possess: radio receiver, colour TV, bicycle or motorbike, car/van for private use, horse, computer, internet connection, mobile phone or landline, washing machine, bed for each household member (including infants), thirty or more books (except school books), and a power generator.
} 
remittances increase the probability of a decision to migrate, and they also influence where one chooses to migrate (Epstein and Gang, 2006; Dimova and Wolff, 2015) ${ }^{7}$.

For instance, the Roma living in Albania report Greece and Italy as their preferred locations, which are already the main destinations of emigrants in that country. Potential Roma emigrants living in Romania are oriented towards Spain and Italy in their plan, which still highlights the role that migrant networks play in driving the potential future migrants. The preferred destinations for the Roma living in Bosnia and Herzegovina are Germany and Sweden, reflecting previous refugee networks that have existed since the Balkan Wars in the 1990s. For the Roma living in Moldova, Russia and Ukraine are the most important preferred locations because of language and cultural links with these countries.

Among the Roma who plan to emigrate to a foreign country, 33.5\% indicate that emigration is likely to occur in less than one year and $29.4 \%$ in more than one year (the remaining proportion having no idea). An expectation to emigrate soon (in less than one year) is more frequently observed among the Roma living in Bosnia and Herzegovina (54.7\%) and Serbia (51.9\%), while it is lower among those living in Croatia (10.0\%) and Albania (11.2\%). The Roma group's main motivation for moving is related to better chances of finding employment (63.4\%), while they less often report better living conditions (15.8\%) and better pay or working conditions (15.5\%). For all countries, job opportunities are the main driver of intended Roma emigration, especially in Albania (88.8\%), Slovakia (78.7\%) and Bulgaria (76.0\%). Better living conditions are a reason which is more frequently observed for the Roma living in Bosnia and Herzegovina (35.9\%) and Montenegro (23.4\%).

In Panel B of Table 3, we also present the pattern of intended migration among the nonRoma. When considering all countries, we find that the non-Roma less frequently express intentions to emigrate to a foreign country (19.7\%). A mean-comparison test shows that the gap amounts to 5.9 percentage points, which is statistically significant. At the country level, the proportion of Roma respondents intending to migrate exceeds that of non-Roma in five out of twelve countries (at the 5 percent level). The highest values for the ethnic gap are observed in the Czech Republic $(+18.9$ percentage points), Bosnia and Herzegovina $(+15.8)$ and Serbia $(+11.5)$. Conversely, ethnicity has no significant influence in Macedonia, Moldova, Montenegro, Romania and Slovakia. The ethnic gap is even negative in Croatia and Hungary.

The destination choices for potential non-Roma emigrants are slightly different. The nonRoma are more confident in choosing far-off countries. For the pooled sample, Germany remains the first destination choice. The United States is the third intended destination. In the Czech Republic, the non-Roma respondents report the United Kingdom, the United States and Canada as their top

\footnotetext{
${ }^{7}$ Migrant networks can provide specific job information, accommodation, supportive relationships and services that reduce the costs of migration.
} 
three preferred destinations. The unfavourable socio-economic characteristics of Roma may be an obstacle to financing the costs of migration, which increase with remote destinations. We also note some differences in the expected timing and the main motives for emigrating to a foreign country. An expectation to emigrate soon (in less than one year) is less frequent among non-Roma (30.0\% compared to $33.5 \%$ for the Roma). Better chances of finding employment are a reason which is less frequently reported among the non-Roma (55.5\%), especially for those living in Montenegro (30.3\%) and the Czech Republic (39.3\%).

To summarize, these descriptive findings show that intentions to emigrate are rather frequent in Central and South-East European countries, and they are more often observed among the Roma (one respondent out of four) compared to the non-Roma (one out of five). Since respondents of the former ethnic group have lower education levels and are more likely to have no job, we turn to an econometric analysis to assess whether there exists an ethnic gap in emigration intentions once individual characteristics are taken into account.

\section{A measurement of the ethnic gap in intended emigration}

We explain the probability of an intended emigration using a latent variable framework. Let $E_{i}$ be a latent variable measuring the propensity that a respondent $i$ has in intending to emigrate. This outcome is supposed to depend on a set of explanatory variables $X_{i}$, which include both individual characteristics and country dummies, and also on an ethnic variable $R_{i}$ such that $R_{i}=1$ when the respondent is of Roma origin and $R_{i}=0$ otherwise:

$$
E_{i}=\delta \tilde{h}_{i}+X_{i} \beta+\varepsilon_{i}
$$

where $\delta$ is our key parameter measuring the ethnic gap, $\beta$ is a vector of coefficients to estimate and $\xi_{i}$ is a random perturbation supposed to be normally distributed. Denoting by $\Sigma_{i}$ the intention of emigration expressed in the survey, we have $E_{i}=1$ when $E_{i}>0$ and $E_{i}=0$ when $E_{i}^{*} \leq 0$. The corresponding specification is a Probit model with $\operatorname{Pr}\left(E_{i}=1\right)=\llbracket\left(\delta \Omega_{i}+X_{i} \beta\right), \Phi$ being the normal distribution function. Estimates with various sets of controls are presented in Table 4.

\section{Insert Table 4}

As a preliminary step, we only include the Roma variable along with country dummies. As shown in column (1), we find a positive correlation between the ethnic dummy and the intention to emigrate. Being that Roma are associated with an increase of 5.9 percentage points in the intended probability to emigrate, which is equal to $22.9 \%$ at the sample means (thus an increase of $25.8 \%$ ). Next, we account for the influence of individual characteristics (column 2). We still get a positive coefficient for the ethnic variable, which remains significant at the one percent level. However, controlling for observed heterogeneity reduces the marginal effect of ethnic origin. At the sample 
means, Roma respondents have an intended probability of emigrating, which is 4.3 percentage points higher when compared to non-Roma.

Many individual characteristics have a significant influence on emigration intentions. Men, single people and young people are more favourably disposed to emigrate. Compared to the youngest age group (less than 25), the probability of intended migration decreases by 11.5 percentage points for the $45-54$ year-old group and by 18.0 points for the $55-64$ year-old group. The intended probability of leaving the origin country is positively correlated with education. Conversely, it is lower for those having a paid activity compared to those not working (-3.1 points). Respondents having more favourable characteristics in terms of labour force participation are more likely to be tempted to leave their origin country ${ }^{8}$. Finally, we find substantial differences depending on the origin country of respondents. Taking Albania as a reference country, this probability is significantly higher only in Serbia ( +5.5 points) ${ }^{9}$. Conversely, it is lower in Montenegro (-18.8 points), Moldova (14.2 points), Macedonia (-12.8 points) and Romania (-10.7 points).

In Table 4, we also present estimates from regressions estimated by ethnicity (see columns 3 and 4). Both for the Roma and non-Roma, women less often report the intention to emigrate (at the 10 percent level for the second group). We can hypothesize that the migration of women more deeply affects the families left behind, particularly in the Roma culture. Roma families typically consist of several generations living together under patriarchal authority. Family ties, social support and the sense of responsibility towards the community are very strong (Ringold et al., 2005). Among the non-Roma, there is a positive correlation between being divorced and the dependent variable. Intentions to emigrate are negatively correlated with age for both groups, but the negative effect of age is higher among non-Roma.

The positive correlation between the likelihood of intended emigration and education is only significant for Roma respondents, while rather similar results concerning activity status are found for both groups. Interestingly, we find opposite coefficients for the asset index variable: a positive one for the Roma and a negative one for the non-Roma (significant at the 10 percent level only). Emigration to a foreign country involves costs (transportation, obtaining visas, etc.) that are more easily afforded by wealthier respondents. The difference between both groups is nonetheless striking. Among the non-Roma, those having good economic conditions in their country tend to be less tempted to leave. Conversely, among the Roma, those who intend to emigrate are more educated and wealthier on average. This suggests that there is some self-selection in the emigration

\footnotetext{
${ }^{8}$ The only exception is the positive coefficient found for those having health problems. Moving abroad may be perceived as a way to receive better health care.

${ }^{9}$ The coefficient is also positive but not significant for respondents living in Bosnia and Herzegovina.
} 
of the Roma, such that those intending to leave have better characteristics in terms of job opportunities abroad ${ }^{10}$.

We rely on a decomposition analysis to further assess how individual characteristics affect the ethnic gap in emigration intentions. Specifically, we seek to partition the difference in intention to emigrate between Roma and non-Roma into two components: one which will reflect the difference in observable characteristics between both groups, and another which will ascertain the difference in the effect of covariates across groups. This corresponds to the Oaxaca-Blinder decomposition originally proposed for studying the wage differential between men and women in the context of linear models (Blinder, 1973; Oaxaca, 1973). While implementing the decomposition is straightforward when the outcome is continuous, the problem is more complex with non-linear models. Over the last few years, several techniques have been suggested for generalizing the BlinderOaxaca decomposition in the case of discrete dependent variables ${ }^{11}$.

In what follows, we rely on the multivariate decomposition described in Powers et al. (2011). The difference in the average probability of intended migration $\bar{p}_{R=1}-\bar{p}_{R=0}$ may be expressed as:

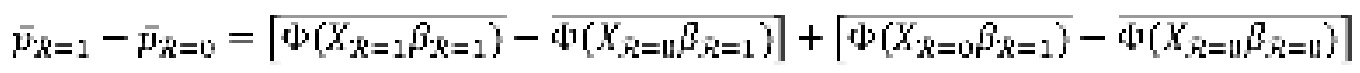

The first-term on the right-hand side in (2) is the part of the ethnic gap attributed to differences in endowments. It reflects the fact that Roma and non-Roma do not have the same observable characteristics on average. The second term is the portion of the ethnic differential due to changes in the coefficient component: the selected characteristics in the non-linear regression do not have the same impact for Roma and non-Roma. In (2), we consider a counterfactual group which is endowed with characteristics of non-Roma respondents.

Using the ethnic-specific estimates reported in columns (3) and (4) of Table 4, we find that the predicted probability in intended emigration (evaluated at the sample means) is $25.6 \%$ among Roma and $19.7 \%$ among non-Roma. Overall, the ethnic gap amounts to 5.9 percentage points. Implementation of the decomposition described in (2) shows that only $2.2 \%$ of this gap is due to differences in individual characteristics between the Roma and non-Roma, and $97.8 \%$ is due to differences in coefficients. So, the ethnic gap in emigration intentions cannot be related to the most disadvantaged observable characteristics of the Roma group in Central and South-East European countries $^{12}$.

\footnotetext{
${ }^{10}$ Living in an urban area also has a positive influence on the intended probability to emigrate for the Roma group only.

${ }^{11}$ See in particular Fairlie (1999), Yun (2004), Bauer and Sinning (2008) and Wolff (2012).

${ }^{12}$ We have also implemented a detailed decomposition indicating the contribution of each covariate to the endowment and coefficient effects. Our results, available upon request, show that age is the most influential covariate when explaining differences in endowments. Age and asset index are those variables contributing the most to the part of the gap attributable to differences in coefficients.
} 
So far, we have assumed that the influence held by individual characteristics on the intention to leave the origin country was the same for all countries. As a final step, we have decided to explore the possibility of heterogeneous ethnic differences in emigration intention by estimating countryspecific Probit regressions. In Figure 3, we restrict our attention to the role played by the Roma dummy. Our results show that the Roma respondents have a higher likelihood of emigration intentions, which is statistically significant in five out of twelve countries. By decreasing order of importance, these countries are: the Czech Republic (+14.6 percentage points), Bosnia and Herzegovina (+14.2 points), Bulgaria (+11.1 points), Serbia (+8.1 points) and Albania (+6.7 points). Conversely, the ethnic gap is not statistically significant in the other countries and the Roma dummy is even negative in four countries (Hungary, Montenegro, Croatia and Slovakia).

Insert Figure 3

\section{Discrimination and emigration intentions}

As they stand, our previous estimates have evidenced differences in the pattern of emigration intentions between the Roma and non-Roma. However, most of this ethnic gap remains unexplained by standard demographic and socio-economic control variables. In what follows, we specifically investigate the potential role of discrimination against the Roma as a factor that can explain this ethnic gap.

Despite the efforts of the European Union, ethnic discrimination currently remains a reality for the Roma across European countries. According to the EU-MIDIS report on discrimination, the Roma are the most discriminated group in Europe (European Union Agency for Fundamental Rights, 2009) ${ }^{13}$. In 2008, 23,500 individuals from ethnic minorities were surveyed in face-to-face questionnaire interviews in 27 Member States of the European Union. Also, 5,000 individuals from the majority population living in the same areas were interviewed. Respondents were asked about discrimination in nine areas: when looking for work, at work, when looking for a house or an apartment to rent or buy, by healthcare personnel, by social service personnel, by school personnel, at a café, restaurant or bar, when entering or being in a shop, and when trying to open a bank account or get a loan. More recently, the economic crisis has certainly contributed to more discrimination against the Roma, especially in the labour market.

From an individual perspective, one difficulty lies in the fact that the perception of discrimination is a sensitive topic to evaluate. Feeling discriminated against is a subjective outcome,

\footnotetext{
${ }^{13}$ The other ethnic groups included people from North-Africa, Sub-Saharan Africa, Turkey, former Yugoslavia, Central Europe, East Europe and Russia.
} 
which may be subject to some justification bias ${ }^{14}$. This would occur if Roma wanted to justify their emigration intentions by indicating that they feel discriminated against in their own country. It should be noted, however, that the EU-MIDIS report on discrimination argues that discrimination against Roma is largely unreported (European Union Agency for Fundamental Rights, 2009). Several explanations may come to mind. First, the Roma are concerned about fear. Second, the Roma are resigned to discrimination against them and have the feeling that nothing would change. Third, the Roma lack knowledge about how to report discrimination ${ }^{15}$.

Interestingly, the Roma Regional Survey includes a specific section about general discrimination and rights awareness. Discrimination is defined as being treated less favourably than others because of a specific personal feature such as age, gender or minority background. Selfassessed discrimination is measured by the following question: "In the past 12 months (or since you have been in the country), have you personally felt discriminated against in (country) on the basis of one or more of the following grounds?". The five items are: "for non-Roma: because of ethnicity / for Roma: because you are a Roma", "because you are a woman/man", "because of your age", "because of your disability", "for another reason".

The pattern of discrimination observed in the Roma Regional Survey is presented in Table 5. Overall, the proportion of respondents who feel discriminated against amounts to $28.8 \%$. It is much higher among Roma (36.3\%) compared to non-Roma (10.2\%). The most common grounds for discrimination is ethnic origin (25.6\%), followed by gender (6.8\%), age (5.8\%) and disability (3.2\%). Ethnicity is the most important factor behind discrimination. $34.1 \%$ of the Roma respondents said that they felt discriminated against in the past 12 months because of their ethnicity (compared to $4.6 \%$ for the non-Roma). The gap is lower, albeit significant, on other grounds. For instance, $8.4 \%$ of the Roma respondents considered that they were discriminated against on the basis of gender compared to $3.0 \%$ for the non-Roma.

\section{Insert Table 5}

Since a substantial proportion of Roma feel discriminated against on the basis of ethnic background, we decided to further investigate the influence of perceived discrimination on emigration intentions. As a preliminary step, we assume that the self-assessed feeling of discrimination is exogenous, meaning that we neglect the potential endogeneity due to some justification bias. Specifically, we introduce discrimination as an additional regressor in the previous Probit models explaining emigration intentions. In Table 6, we present the marginal effects from

\footnotetext{
${ }^{14}$ In a study on what drives retirement plans, Parsons (1980) notes that respondents can misreport subjective measures regarding their health to justify their early retirement and to benefit from financial compensation.

${ }^{15}$ The survey asked respondents to identify any organisation in their country that can offer support against discrimination. Between $71 \%$ and $94 \%$ of Roma respondents could not name any organisation (European Union Agency for Fundamental Rights, 2009).
} 
Probit models for the discrimination variable. In column (1), we report the marginal effect associated with the Roma dummy. In column (2), we investigate how this coefficient changes when taking discrimination into account. In column (3), we implement the same regression for the Roma subsample.

\section{Insert Table 6}

Considering all respondents (Panel A), the probability of emigration intentions is 4.3 percentage points higher for the Roma. This marginal effect is divided by nearly two when the feeling of being discriminated is introduced. At the same time, the intention to emigrate is 10.3 points higher for those respondents reporting any form of discrimination against them. This positive correlation still holds when restricting the sample to the Roma group. For those feeling discriminated against, the probability of emigration intention is 10.7 points higher. In Panel B, we focus only on discrimination because of ethnicity. We find very similar results, which is not really surprising given the contribution of the ethnic dimension to total discrimination. As shown in column (2), respondents claiming that they feel discriminated against because of their ethnicity have a much higher probability to emigrate (+11.1 points $)^{16}$.

In Panels $\mathrm{C}$ and $\mathrm{D}$, we introduce more detailed information by considering situations in which respondents have been discriminated against: "during the last 5 years (or, if less than 5 years, since you have been in the country), have you ever been discriminated against in [country] a) when looking for a paid job? b) at work by people who you work for or work with?". Possible answers are "for Roma: because of being Roma / for non-Roma: because of ethnicity" and "because of other reasons (gender, age, disability, etc.)". In Panel C, we focus on respondents who look for paid work or have looked for paid work in the past five years. For that subsample, emigration intentions are positively correlated with ethnic discrimination at the 1 percent level (+10.2 points). Conversely, the relationship is not statistically significant with discrimination because of other reasons. The same pattern is found for respondents having a job (Panel D). People reporting discrimination because of ethnicity are more likely to plan to go abroad ( +13.3 points), while the correlation with the other forms of discrimination is negative though not significant.

In summary, our estimates in Table 6 are consistent with our previous findings, which show that prospects in the labour market serve as the main motivation for leaving the country. The problem of discrimination in the labour market appears to be a central element behind the emigration intentions of the Roma. The main difficulty at this stage is that our self-assessed measure of discrimination is likely to be endogenous. In our context, there are two potential sources of

\footnotetext{
${ }^{16}$ When taking discrimination into account, we note that the Roma dummy is no longer significant. An explanation is that the ethnic dimension is implicitly captured by the variable measuring self-assessed discrimination.
} 
endogeneity. A first issue is the presence of unobserved heterogeneity (omitted variables). The same unobservable characteristics of the respondents may influence both the emigration intention and perceived discrimination. Unfortunately, there is nothing that we can really do concerning this issue, since the Regional Roma Survey is a cross-sectional household survey ${ }^{17}$. A second issue is that endogeneity may stem from simultaneity. In particular, respondents can misreport their feeling of discrimination as a way to justify their intentions to emigrate.

In what follows, we consider an instrumental variable approach to address the endogeneity of the discrimination outcome. The main difficulty is to find at least one instrument that is highly correlated with the endogenous feeling of discrimination but has no influence on emigration intentions (other than through discrimination). We proceed in the following way with our data. First, we decide to restrict our attention to the Roma sample, as the most common ground for discrimination is related to ethnicity. Thus, we seek to assess whether Roma respondents are more likely or not to leave their origin country when they feel discriminated against. Second, we construct an instrument which is the proportion of people living in the same city and having suffered from discrimination due to their ethnicity in the past twelve months ${ }^{18}$. We also calculate the proportion of people of the same sex living in the same city and who are victims of discrimination.

The choice of this local instrument may be justified in the following way. On the one hand, if ethnic discrimination exists, it is expected to affect all people characterized by the same ethnic background and facing similar local conditions, for instance in terms of labour market, schools or health facilities. Thus, our measure of local intensity of discrimination should be highly correlated with the individual feeling of having felt personally discriminated against. This expectation is consistent with our data, since we find a coefficient of correlation equal to 0.409 between the individual feeling of discrimination and the proportion of Roma respondents living in the same city who have felt discriminated against because of ethnicity ${ }^{19}$. On the other hand, our local instrument should be uncorrelated with the residual of a regression explaining the intention to emigrate.

Among the various factors explaining emigration, several studies have described the role played by individual preferences, wage differentials between the origin and destination countries, familial considerations and social networks (Dustmann, 2003; Epstein and Gang, 2006). In our context, it is not certain at all that respondents will be aware of whether Roma people living around them have been victims of any forms of ethnic discrimination. Even if that were the case, emigration

\footnotetext{
${ }^{17}$ The UNDP/WB/EC explains this choice because of the time frame of the Regional Roma Survey. A longitudinal survey requires a long-term investment. In addition, the suspicion of the Roma towards the majority population needs to be taken into account (Cherkezova and Tomova, 2013).

${ }^{18}$ For each respondent, we excluded his/her own answer when calculating this ratio.

${ }^{19}$ The coefficient of correlation is equal to 0.382 when considering the local proportion of respondents of the same sex having felt discriminated against.
} 
remains costly and Roma respondents are expected to be much more sensitive to their own experiences than to those of other people living nearby. Using a linear probability model, we express the intention to emigrate as a function of both the personal experience of discrimination and the local intensity of discrimination reported by people living in the same city (in addition to individual characteristics). While the correlation is positive and highly significant for the former explanatory variable, the local intensity of discrimination does not influence emigration intentions ${ }^{20}$.

To begin with, we study the effect of discrimination on emigration intentions among the Roma using linear probability models. Under exogeneity, we find that intentions to emigrate are 10.7 percentage points higher for those respondents who were discriminated against over the previous 12 months. In Panel A of Table 7, we report the endogeneity-corrected estimator with the proportion of Roma victims of ethnic discrimination at the city level. As shown in column (1), the corresponding coefficient is now substantially higher (+17.6 percentage points) and significant. In Panel B, we use the local instrument calculated at the gender-city level. The IV estimate is slightly lower $(+14.4$ percentage points) but still shows the importance of discrimination when attempting to explain why the Roma intend to emigrate internationally.

\section{Insert Table 7}

A shortcoming of the linear probability model is that our dependent variable (emigration intention) is binary and not continuous. Since the endogenous variable (discrimination) is also binary, we decided to estimate a bivariate Probit model. This recursive model comprises two equations: a first equation explains the intention to emigrate as a function of individual characteristics and the endogenous feeling of discrimination, and a second equation explains the feeling of discrimination. The crucial assumption here is that the residuals of both equations follow a joint normal distribution. In Table 7, we report the marginal effect of the endogenous feeling of discrimination. Standard errors are obtained from a bootstrap procedure with 250 replications. We find very similar results compared to those of the linear probability model. Depending on the instrument (either calculated at the city or the city-gender level), the probability of emigration intention increases by 13-16 percentage points among the Roma when the respondent has experienced discrimination over the last year.

As a final step, we turn to the special regressor estimator proposed in Lewbel (2000). Lewbel et al. (2012) have shown that both the linear probability and bivariate models could lead to biased estimates for the endogenous covariate in a discrete econometric framework. We assume that there exists one special regressor satisfying the following properties: i) it is exogenous and appears

\footnotetext{
${ }^{20}$ We also calculate the correlation between the instrument and the residual of a regression that explains emigration intention as a function of the individual feeling of discrimination along with individual characteristics. This correlation is very low, equal to 0.020 , and not statistically significant.
} 
additively to the error term; ii) it is continuously distributed and is characterized by a large support; and iii) it preferably has a thick-tailed distribution. The special regressor estimator imposes very few assumptions on the distribution of the error terms; thus, it is expected to be less efficient and to have larger standard errors compared to other estimators ${ }^{21}$.

In our analysis, we choose the opposite of the respondent's age as a special regressor. This covariate is clearly exogenous, and our previous estimates reported in Table 3 have shown that the probability to emigrate was a decreasing function of age (so that it increases with negative age). As shown in Table 7, the marginal effect of the discrimination variable is now lower with the special regressor estimator when compared to the linear probability and bivariate Probit estimates ${ }^{22}$. When the instrument is calculated at the city level, the probability of emigration intention increases by 6.2 percentage points. The marginal effect is slightly higher ( +8.2 percentage points) when the instrument is calculated at the city-gender level. Consequently, our results suggest that both the linear probability and bivariate Probit models tend to overstate the effect of discrimination on emigration intentions. At the same time, the feeling of ethnic discrimination plays a major role within the Roma population when explaining the intention to leave the country.

\section{Conclusions}

The issue of Roma emigration has increasingly attracted the attention of both the media and policy makers over the last several years. The characteristics of this ethnic group (young, poor, stereotyped) seem to have accentuated concerns about the implications of their movements to Western European countries. However, little attempt has been made by academics to explore the important issue of the potential size of Roma migration outflows, the motivations of potential emigrants or the factors explaining emigration intentions. In this paper, we have attempted to close this gap in the empirical literature by studying the patterns and determinants of emigration intentions among the Roma.

For this purpose, we have used a unique household survey conducted in twelve countries of Central and Southeast Europe, which are well-known as primary exporters of migrants in the world and have significant shares of Roma in their population. Our results show that one Roma out of four intends to emigrate abroad. Emigration intentions are significantly more important among the Roma compared to the non-Roma even after taking demographic and socio-economic characteristics into account, but the gap remains low (around 4 percentage points). Interestingly, among the Roma, those who intend to emigrate are more educated and wealthier on average. Finally, ethnic

\footnotetext{
${ }^{21}$ For a detailed presentation of the estimation technique, see Dong and Lewbell (2015).

22 The number of observations is reduced (from 8,285 to 8,203) since the data are trimmed by one percent to ensure adequate support.
} 
discrimination seems to be one of the main push factors explaining the greater willingness to emigrate that is observed among the Roma.

Overall, our empirical results provide a better understanding of the emigration intentions of the Roma population from a comparative perspective. They may contribute to improved socioeconomic policies towards the Roma in an enlarged Europe, especially regarding the issue of discrimination. In the future, it would be useful to collect longitudinal data on the Roma population. This would allow estimation of the role that individual characteristics play in emigration intentions, net of the influence of unobserved heterogeneity. Also, it would be of interest to have more information on why the Roma intend to emigrate to a specific country. This would allow us to investigate how emigration is influenced by migrant networks in the host country as well as by social and labour market policies. 


\section{References}

Bauer T., Sinning M., (2008), "An extension of the Blinder-Oaxaca decomposition to nonlinear models", Advances in Statistical Analysis, vol. 92, pp. 197-206.

Blinder A.S, (1973), "Wage discrimination: Reduced form and structural estimates", Journal of Human Resources, vol. 8, pp. 436-455.

Cherkezova S., Tomova I., (2013), "An option of last resort? Migration of Roma and non-Roma from CEE countries", Working Paper, United Nations Development Programme.

van Dalen H., Groenewold G., Fokkema T., (2005a), "The effect of remittances on emigration intentions in Egypt, Morocco and Turkey", Population Studies, vol. 59, pp. 375-392.

van Dalen H., Groenewold G., Fokkema T., (2005b), "Out of Africa: what drives the pressure to emigrate ?", Journal of Population Economics, vol. 18, pp. 741-778.

van Dalen H., Hendrik P., Henkens K., (2013), "Explaining emigration intentions and the behaviour in the Netherlands, 2005-10", Population Studies: A Journal of Demography, vol. 67, pp. 225241.

Dimova R., Wolff F.C., (2015), "Remittances and chain migration: Longitudinal evidence from Bosnia and Herzegovina", Journal of Development Studies, forthcoming.

Dong Y., Lewbel A., (2015), "A simple estimator for binary choice models with endogenous regressors", Econometric Reviews, vol. 34, pp. 82-105.

Dustmann C., (2003), "Children and return migration", Journal of Population Economics, vol. 16, pp. $815-830$.

Epstein G.S, Gang I., (2006), "The influence of others on migration plans", Review of Development Economics, vol. 10, pp. 652-665.

European Commission, (2011), "An EU framework for national Roma Integration strategies up to 2020", Communication from the Commission to the European Parliament, the Council, the European economic and social committee and the Committee of the regions, Brussels, 173.

European Union Agency for Fundamental Rights, (2009), EU-MIDIS European Union Minorities and Discrimination Survey Data in Focus Report 1: The Roma, Budapest.

Fairlie R.W., (1999), "The absence of the African-American owned business: An analysis of the dynamics of self-employment", Journal of Labour Economics, vol. 17, pp. 80-108.

Filmer D., Pritchett L.H., (2001), "Estimating wealth effect without expenditure data or tears: An application to educational enrollments in states of India", Demography, vol. 38, pp. 115-132.

Gordon I., Molho I., (1995), "Duration dependence in migration behaviour: Cumulative inertia versus stochastic change", Environment and Planning, vol. 27, pp. 1961-1975.

Kertesi G., Kézdi G., (2011a), "Roma employment in Hungary after the post-communist transition", Economics of Transition, vol. 19, pp. 563-610.

Kertesi G., Kézdi G., (2011b), "The Roma/non-Roma test score gap in Hungary", American Economic Review, vol. 101, pp. 519-525.

Lewbel A., (2000), "Semiparametric qualitative response model estimation with unknown heteroskedasticity or instrumental variables", Journal of Econometrics, vol. 97, pp. 145-177.

Lewbel A., Dong Y., Yang T.T., (2012), "Comparing features of convenient estimators for binary choice models with endogenous regressors", Canadian Journal of Economics, vol. 45, pp. 809-829. 
Oaxaca R.L., (1973), "Male-female wage differentials in urban labour markets", International Economic Review, vol. 14, pp. 693-709.

O'Higgins N., (2010), “"It's not that I'm a racist, it's that they are Roma": Roma discrimination and returns to education in South Eastern Europe", International Journal of Manpower, vol. 31, pp. 163-187.

Parsons D.O, (1980), "The decline in male labour force participation", Journal of Political Economy, vol. 88, pp. 117-134.

Ringold D., Orenstein M.A., Wilkens E., (2005), Roma in an Expanding Europe: Breaking the Poverty Cycle, Washington DC, The World Bank.

Senik C., (2005), "What can we learn from subjective data? The case of income and wellbeing", Journal of Economic Surveys, vol. 19, pp. 43-63.

Wolff F.C., (2012), "Decomposition of non-linear models using simulated residuals", Economics Letters, vol. 116, pp. 346-348.

World Bank, (2011), Migration and Remittances Factbook, Washington DC, The World Bank.

Yun M.S., (2004), "Decomposition differences in the first moment", Economics Letters, vol. 82, pp. 275-280. 
Table 1. Selected characteristics of Central and South-East European countries

\begin{tabular}{|c|c|c|c|c|c|c|c|c|c|c|c|}
\hline \multirow[t]{2}{*}{ Country } & \multirow{2}{*}{$\begin{array}{l}\text { Total country } \\
\text { population } \\
\text { (2009) }\end{array}$} & \multicolumn{4}{|c|}{ Roma population (2009) } & \multirow[b]{2}{*}{$\begin{array}{l}\text { GDP per } \\
\text { capita PPP } \\
\text { constant } \\
\text { international } \\
\$(2011)\end{array}$} & \multirow[b]{2}{*}{$\begin{array}{l}\text { Poverty } \\
\text { headcount } \\
\text { ratio at nat. } \\
\text { poverty line, } \\
\% \text { of pop. } \\
\text { (2011) }\end{array}$} & \multirow{2}{*}{$\begin{array}{l}\text { Unemployme } \\
\mathrm{nt} \text { \% of total } \\
\text { labour force } \\
\text { ILO(2011) }\end{array}$} & \multirow{2}{*}{$\begin{array}{l}\text { EU Member } \\
\text { State }\end{array}$} & \multirow{2}{*}{$\begin{array}{l}\text { Stock of } \\
\text { emigrant, \% } \\
\text { of population } \\
\text { (2010) }\end{array}$} & \multirow{2}{*}{$\begin{array}{l}\text { Top three destination countries } \\
(2010)\end{array}$} \\
\hline & & $\begin{array}{l}\text { Minimum } \\
\text { estimate }\end{array}$ & $\begin{array}{l}\text { Maximum } \\
\text { estimate }\end{array}$ & $\begin{array}{l}\text { Average } \\
\text { estimate }\end{array}$ & $\begin{array}{l}\% \text { of total } \\
\text { population }\end{array}$ & & & & & & \\
\hline Albania & $3,619,778$ & 80,000 & 150,000 & 115,000 & 3.18 & 9,122 & 14.3 & 14.3 & No & 45.4 & Greece, Italy, Macedonia \\
\hline Bosnia and Herzegovina & $4,590,310$ & 40,000 & 60,000 & 50,000 & 1.09 & 9,235 & 17.9 & 27.6 & No & 38.9 & Croatia, Germany, Austria \\
\hline Bulgaria & $7,262,675$ & 700,000 & 800,000 & 750,000 & 10.33 & 15,523 & 21.2 & 11.3 & Yes (2007) & 16 & Turkey, Spain, Germany \\
\hline Croatia & $4,491,543$ & 30,000 & 40,000 & 35,000 & 0.78 & 20,286 & 20.5 & 13.4 & Yes (2013) & 17.1 & Germany, Austria, the United States \\
\hline Czech Republic & $10,220,911$ & 150,000 & 250,000 & 200,000 & 1.96 & 27,047 & 9.6 & 6.7 & Yes (2004) & 3.6 & Slovakia, Germany, Austria \\
\hline Hungary & $9,930,915$ & 400,000 & $1,000,000$ & 700,000 & 7.05 & 22,413 & 14.0 & 10.9 & Yes (2004) & 4.6 & Germany, the United States, Canada \\
\hline Macedonia & $2,061,315$ & 135,500 & 260,000 & 197,750 & 9.59 & 11,749 & 27.1 & 31.4 & No & 21.9 & Italy, Germany, Austria \\
\hline Moldova & $4,324,450$ & 15,000 & 200,000 & 107,500 & 2.49 & 4,179 & 17.5 & 6.7 & No & 21.5 & Russia, Ukraine, Italy \\
\hline Montenegro & 678,177 & 15,000 & 25,000 & 20,000 & 2.95 & 14,127 & 9.3 & 19.7 & No & NA & NA \\
\hline Romania & $22,246,862$ & $1,200,000$ & $2,500,000$ & $1,850,000$ & 8.32 & 17,113 & 22.6 & 7.4 & Yes (2007) & 13.1 & Italy, Spain, Hungary \\
\hline Serbia & $7,334,935$ & 400,000 & 800,000 & 600,000 & 8.18 & 11,731 & 24.6 & 19.1 & No & 2.0 & Austria, the United States, France \\
\hline Slovakia & $5,455,407$ & 400,000 & 600,000 & 500,000 & 9.17 & 28,156 & 13.2 & 8.2 & Yes (2004) & 9.6 & Czech Republic, Hungary, Ukraine \\
\hline
\end{tabular}

Source: population data are from the Council of Europe Roma and Travellers Division. Data on GDP, poverty and unemployment are from the World Development Indicators; data on migration are from the Migration and Remittances Factbook. 
Table 2. Descriptive statistics of the sample

\begin{tabular}{lllll}
\hline Variables & All & Roma & Non-Roma & Difference \\
\hline Female & 0.574 & 0.576 & 0.571 & 0.005 \\
Age & 37.477 & 36.093 & 40.927 & $-4.834^{* * *}$ \\
In a couple & 0.693 & 0.712 & 0.648 & $0.064^{* * *}$ \\
Divorced - separated & 0.079 & 0.078 & 0.080 & -0.001 \\
Widowed & 0.061 & 0.060 & 0.064 & -0.004 \\
Single & 0.167 & 0.150 & 0.208 & $-0.058^{* * *}$ \\
Household size & 4.258 & 4.613 & 3.375 & $1.238^{* * *}$ \\
Health problems & 0.224 & 0.239 & 0.186 & $0.053^{* * *}$ \\
No formal education & 0.186 & 0.253 & 0.017 & $0.237^{* * *}$ \\
Primary education & 0.208 & 0.266 & 0.063 & $0.203^{* * *}$ \\
Lower secondary education & 0.338 & 0.362 & 0.277 & $0.085^{* * *}$ \\
Upper/post-secondary education & 0.268 & 0.118 & 0.643 & $-0.525^{* * *}$ \\
Paid activity - self-employed & 0.306 & 0.252 & 0.441 & $-0.189^{* * *}$ \\
Homemaker - parental leave & 0.189 & 0.210 & 0.136 & $0.075^{* * *}$ \\
Retired & 0.083 & 0.059 & 0.141 & $-0.082^{* * *}$ \\
Not working - other & 0.422 & 0.479 & 0.282 & $0.197^{* * *}$ \\
Asset index & 0.045 & -0.529 & 1.477 & $-2.006^{* * *}$ \\
Capital/district centre & 0.331 & 0.326 & 0.343 & $-0.017^{*}$ \\
Town & 0.262 & 0.263 & 0.258 & 0.005 \\
Village/unregulated area & 0.407 & 0.411 & 0.399 & 0.012 \\
\hline Number of respondents & 11,609 & 8,285 & 3,324 & \\
\hline
\end{tabular}

Source: authors' calculations, UNDP/WB/EC Regional Roma Survey 2011.

Note: significance levels are $1 \%\left({ }^{* * *}\right), 5 \%\left({ }^{* *}\right)$ and $10 \%\left({ }^{*}\right)$, respectively. 
Table 3. Pattern of migration intention, by ethnicity and country

\begin{tabular}{|c|c|c|c|c|c|c|c|c|c|c|c|c|c|c|}
\hline Variables & & 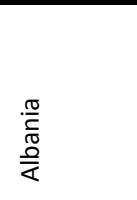 & 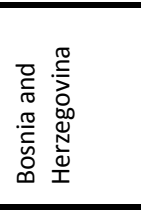 & $\begin{array}{l}\frac{\pi}{\pi} \\
\frac{0}{\pi} \\
\frac{.0}{5} \\
0\end{array}$ & $\begin{array}{l}\stackrel{0}{0} \\
\stackrel{0}{0} \\
\stackrel{0}{0}\end{array}$ & 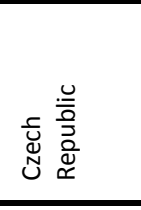 & $\begin{array}{l}\frac{2}{0} \\
0 \\
00 \\
5 \\
3 \\
1\end{array}$ & 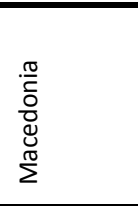 & 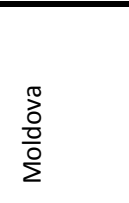 & 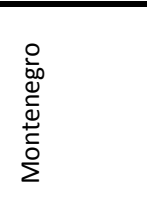 & $\begin{array}{l}\frac{\pi}{\pi} \\
\frac{\pi}{\pi} \\
\stackrel{0}{\delta} \\
\propto\end{array}$ & 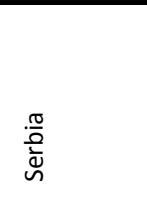 & $\begin{array}{l}\frac{\pi}{\frac{\pi}{\omega}} \\
\frac{\partial}{\omega}\end{array}$ & $\bar{\varepsilon}$ \\
\hline \multicolumn{15}{|l|}{ Panel A. Roma } \\
\hline \multicolumn{2}{|c|}{ Plan to move to another country } & 0.375 & 0.421 & 0.247 & 0.171 & 0.283 & 0.244 & 0.200 & 0.149 & 0.106 & 0.194 & 0.438 & 0.227 & 0.256 \\
\hline \multirow[t]{3}{*}{ Intended place } & First country & Greece & Germany & Germany & Germany & UK & Germany & Germany & Russia & Germany & Spain & Germany & UK & Germany \\
\hline & Second country & Italy & USA & Greece & Italy & Canada & Canada & Belgium & Ukraine & Italy & Italy & Austria & Czech R. & UK \\
\hline & Third country & UK & Sweden & Italy & Switzerl. & USA & UK & Italy & Italy & Sweden & Germany & Sweden & Germany & Greece \\
\hline \multirow[t]{3}{*}{ Expected timing } & In less than one year & 0.112 & 0.547 & 0.331 & 0.100 & 0.229 & 0.380 & 0.302 & 0.215 & 0.234 & 0.392 & 0.519 & 0.299 & 0.335 \\
\hline & In more than one year & 0.340 & 0.215 & 0.266 & 0.433 & 0.383 & 0.240 & 0.410 & 0.215 & 0.286 & 0.285 & 0.256 & 0.274 & 0.294 \\
\hline & Don't know & 0.549 & 0.238 & 0.403 & 0.467 & 0.388 & 0.380 & 0.288 & 0.570 & 0.481 & 0.323 & 0.225 & 0.427 & 0.371 \\
\hline \multirow[t]{4}{*}{ Main motive } & Better chances of finding empl. & 0.888 & 0.510 & 0.760 & 0.667 & 0.484 & 0.485 & 0.439 & 0.667 & 0.494 & 0.685 & 0.641 & 0.787 & 0.634 \\
\hline & Better pay/working conditions & 0.030 & 0.107 & 0.162 & 0.142 & 0.197 & 0.281 & 0.237 & 0.204 & 0.117 & 0.169 & 0.175 & 0.134 & 0.155 \\
\hline & Better living conditions & 0.045 & 0.359 & 0.007 & 0.150 & 0.234 & 0.135 & 0.223 & 0.097 & 0.234 & 0.123 & 0.159 & 0.037 & 0.158 \\
\hline & Other reasons & 0.037 & 0.024 & 0.071 & 0.042 & 0.085 & 0.099 & 0.101 & 0.032 & 0.156 & 0.023 & 0.025 & 0.043 & 0.053 \\
\hline \multicolumn{15}{|c|}{ Panel B. Non-Roma } \\
\hline \multicolumn{2}{|c|}{ Plan to move to another country } & 0.263 & 0.263 & 0.171 & 0.232 & 0.094 & 0.260 & 0.168 & 0.124 & 0.104 & 0.162 & 0.323 & 0.197 & 0.197 \\
\hline \multirow[t]{3}{*}{ Intended place } & First country & Italy & Germany & Germany & Germany & UK & Germany & Germany & Russia & Germany & Spain & Switzerl. & UK & Germany \\
\hline & Second country & Greece & Switzerl. & UK & Switzerl. & USA & Austria & Kosovo & Italy & Switzerl. & Germany & Germany & Ireland & Italy \\
\hline & Third country & USA & USA & France & Italy & Canada & Italy & Switzerl. & Canada & USA & France & Austria & Hungary & USA \\
\hline \multirow[t]{3}{*}{ Expected timing } & In less than one year & 0.195 & 0.513 & 0.270 & 0.097 & 0.321 & 0.343 & 0.208 & 0.226 & 0.182 & 0.270 & 0.467 & 0.279 & 0.300 \\
\hline & In more than one year & 0.439 & 0.308 & 0.487 & 0.403 & 0.286 & 0.284 & 0.604 & 0.452 & 0.455 & 0.432 & 0.272 & 0.197 & 0.367 \\
\hline & Don't know & 0.366 & 0.180 & 0.243 & 0.500 & 0.393 & 0.373 & 0.188 & 0.323 & 0.364 & 0.297 & 0.261 & 0.525 & 0.332 \\
\hline \multirow[t]{4}{*}{ Main motive } & Better chances of finding empl. & 0.732 & 0.449 & 0.703 & 0.419 & 0.393 & 0.448 & 0.521 & 0.548 & 0.303 & 0.541 & 0.630 & 0.754 & 0.555 \\
\hline & Better pay/working conditions & 0.134 & 0.141 & 0.216 & 0.194 & 0.357 & 0.254 & 0.104 & 0.194 & 0.364 & 0.270 & 0.207 & 0.115 & 0.195 \\
\hline & Better living conditions & 0.049 & 0.385 & 0.027 & 0.210 & 0.214 & 0.134 & 0.250 & 0.161 & 0.303 & 0.162 & 0.120 & 0.066 & 0.169 \\
\hline & Other reasons & 0.085 & 0.026 & 0.054 & 0.177 & 0.036 & 0.164 & 0.125 & 0.097 & 0.030 & 0.027 & 0.044 & 0.066 & 0.081 \\
\hline \multicolumn{2}{|c|}{ Roma vs. non-Roma gap in emigration intention } & $0.112 * * *$ & $0.158^{* * *}$ & $0.076 * *$ & $-0.061^{* *}$ & $0.189 * * *$ & -0.016 & 0.032 & 0.025 & 0.002 & 0.032 & $0.115^{* * *}$ & 0.030 & $0.059 * * *$ \\
\hline
\end{tabular}

Source: authors' calculations, UNDP/WB/EC Regional Roma Survey 2011. 
Table 4. Probit estimates of the determinants of emigration intention

\begin{tabular}{|c|c|c|c|c|c|}
\hline \multicolumn{2}{|l|}{ Variables } & (1) All & (2) All & (3) Roma & (4) Non-Roma \\
\hline \multicolumn{2}{|l|}{ Constant } & $\begin{array}{l}-0.551^{* * *} \\
(-12.13)\end{array}$ & $\begin{array}{l}-0.375^{* * *} \\
(-4.43)\end{array}$ & $\begin{array}{l}-0.193^{* *} \\
(-2.13)\end{array}$ & $\begin{array}{l}-0.231 \\
(-0.88)\end{array}$ \\
\hline \multicolumn{2}{|l|}{ Roma } & $\begin{array}{l}0.200^{* * *} \\
(6.73)\end{array}$ & $\begin{array}{l}0.150^{* * *} \\
(3.72)\end{array}$ & & \\
\hline \multicolumn{2}{|l|}{ Female } & & $\begin{array}{l}-0.114^{* * *} \\
(-3.80)\end{array}$ & $\begin{array}{l}-0.118^{* * *} \\
(-3.28)\end{array}$ & $\begin{array}{l}-0.103^{*} \\
(-1.84)\end{array}$ \\
\hline \multirow[t]{4}{*}{$\begin{array}{l}\text { Age } \\
\text { (ref: <25) }\end{array}$} & $25-34$ & & $\begin{array}{l}-0.078^{* *} \\
(-1.98)\end{array}$ & $\begin{array}{l}-0.033 \\
(-0.73)\end{array}$ & $\begin{array}{l}-0.269 * * * \\
(-3.04)\end{array}$ \\
\hline & $35-44$ & & $\begin{array}{l}-0.256^{* * *} \\
(-5.86)\end{array}$ & $\begin{array}{l}-0.201 * * * \\
(-4.02)\end{array}$ & $\begin{array}{l}-0.507^{* * *} \\
(-5.34)\end{array}$ \\
\hline & $45-54$ & & $\begin{array}{l}-0.445^{* * *} \\
(-8.96)\end{array}$ & $\begin{array}{l}-0.370^{* * *} \\
(-6.39)\end{array}$ & $\begin{array}{l}-0.753^{* * *} \\
(-7.32)\end{array}$ \\
\hline & $55-64$ & & $\begin{array}{l}-0.789 * * * \\
(-12.28)\end{array}$ & $\begin{array}{l}-0.708^{* * *} \\
(-9.33)\end{array}$ & $\begin{array}{l}-1.127^{* * *} \\
(-8.91)\end{array}$ \\
\hline \multirow[t]{3}{*}{$\begin{array}{l}\text { Marital status } \\
\text { (ref: In a couple) }\end{array}$} & Divorced - separated & & $\begin{array}{l}0.049 \\
(0.94)\end{array}$ & $\begin{array}{l}-0.004 \\
(-0.06)\end{array}$ & $\begin{array}{l}0.202^{*} \\
(1.95)\end{array}$ \\
\hline & Widowed & & $\begin{array}{l}-0.063 \\
(-0.90)\end{array}$ & $\begin{array}{l}-0.120 \\
(-1.46)\end{array}$ & $\begin{array}{l}0.085 \\
(0.61)\end{array}$ \\
\hline & Single & & $\begin{array}{l}0.077^{*} \\
(1.94)\end{array}$ & $\begin{array}{l}0.080^{*} \\
(1.68)\end{array}$ & $\begin{array}{l}-0.029 \\
(-0.37)\end{array}$ \\
\hline \multicolumn{2}{|l|}{ Household size } & & $\begin{array}{l}0.007 \\
(1.09)\end{array}$ & $\begin{array}{l}0.007 \\
(0.92)\end{array}$ & $\begin{array}{l}0.015 \\
(0.80)\end{array}$ \\
\hline \multicolumn{2}{|l|}{ Health problems } & & $\begin{array}{l}0.165^{* * *} \\
(4.49)\end{array}$ & $\begin{array}{l}0.153^{* * *} \\
(3.64)\end{array}$ & $\begin{array}{l}0.171^{* *} \\
(2.12)\end{array}$ \\
\hline \multirow[t]{3}{*}{$\begin{array}{l}\text { Education } \\
\text { (ref: No formal) }\end{array}$} & Primary & & $\begin{array}{l}0.075^{*} \\
(1.70)\end{array}$ & $\begin{array}{l}0.071 \\
(1.58)\end{array}$ & $\begin{array}{l}0.066 \\
(0.28)\end{array}$ \\
\hline & Lower secondary & & $\begin{array}{l}0.181^{* * *} \\
(4.25)\end{array}$ & $\begin{array}{l}0.174^{* * *} \\
(3.81)\end{array}$ & $\begin{array}{l}0.096 \\
(0.45)\end{array}$ \\
\hline & Upper/post-secondary & & $\begin{array}{l}0.156^{* * *} \\
(2.91)\end{array}$ & $\begin{array}{l}0.183^{* * *} \\
(2.95)\end{array}$ & $\begin{array}{l}0.082 \\
(0.38)\end{array}$ \\
\hline \multicolumn{2}{|c|}{ (ref: Not working - other) } & & $\begin{array}{l}-0.107^{* * *} \\
(-3.11)\end{array}$ & $\begin{array}{l}-0.100 * * \\
(-2.44)\end{array}$ & $\begin{array}{l}-0.134^{* *} \\
(-2.01)\end{array}$ \\
\hline \multicolumn{2}{|r|}{ Homemaker - parental leave } & & $\begin{array}{l}-0.101^{* *} \\
(-2.55)\end{array}$ & $\begin{array}{l}-0.084^{*} \\
(-1.88)\end{array}$ & $\begin{array}{l}-0.128 \\
(-1.42)\end{array}$ \\
\hline \multicolumn{2}{|r|}{ Retired } & & $\begin{array}{l}-0.347^{* * *} \\
(-4.72)\end{array}$ & $\begin{array}{l}-0.258^{* * *} \\
(-2.81)\end{array}$ & $\begin{array}{l}-0.536^{* * *} \\
(-4.17)\end{array}$ \\
\hline \multicolumn{2}{|l|}{ Asset index } & & $\begin{array}{l}0.010 \\
(1.06)\end{array}$ & $\begin{array}{l}0.023^{* *} \\
(2.06)\end{array}$ & $\begin{array}{l}-0.031^{*} \\
(-1.72)\end{array}$ \\
\hline $\begin{array}{l}\text { Location: } \\
\text { (ref: Village/unregu }\end{array}$ & $\begin{array}{l}\text { Capital/district centre } \\
\text { ulated area) }\end{array}$ & & $\begin{array}{l}0.113^{* * *} \\
(3.21)\end{array}$ & $\begin{array}{l}0.120^{* * *} \\
(2.90)\end{array}$ & $\begin{array}{l}0.088 \\
(1.27)\end{array}$ \\
\hline & Town & & $\begin{array}{l}0.008 \\
(0.24)\end{array}$ & $\begin{array}{l}-0.002 \\
(-0.05)\end{array}$ & $\begin{array}{l}0.039 \\
(0.57)\end{array}$ \\
\hline Country dummies & & YES & YES & YES & YES \\
\hline Number of responc & dents & 11,609 & 11,609 & 8,285 & 3,324 \\
\hline
\end{tabular}

Source: authors' calculations, UNDP/WB/EC Regional Roma Survey 2011.

Note: estimates from Probit models, with robust standard errors. Significance levels are $1 \%(* * *), 5 \%(* *)$ and $10 \%(*)$, respectively. 
Table 5. Self-assessment of discrimination

\begin{tabular}{lllll}
\hline Discrimination & $(1)$ All & (2) Roma & $(3)$ Non-Roma & (4) Difference \\
\hline Because of ethnicity & 0.256 & 0.341 & 0.046 & $0.295^{* * *}$ \\
& $(0.437)$ & $(0.474)$ & $(0.210)$ & $(0.006)$ \\
Because of gender & 0.068 & 0.084 & 0.030 & $0.054^{* * *}$ \\
& $(0.252)$ & $(0.277)$ & $(0.170)$ & $(0.005)$ \\
Because of age & 0.058 & 0.065 & 0.042 & $0.023^{* * *}$ \\
& $(0.234)$ & $(0.246)$ & $(0.200)$ & $(0.005)$ \\
Because of disability & 0.032 & 0.038 & 0.017 & $0.021^{* * *}$ \\
For another reason & $(0.176)$ & $(0.190)$ & $(0.131)$ & $(0.004)$ \\
& 0.031 & 0.034 & 0.022 & $0.012^{* * *}$ \\
\hline Any form of discrimination & $(0.173)$ & $(0.182)$ & $(0.147)$ & $(0.004)$ \\
\hline
\end{tabular}

Source: authors' calculations, UNDP/WB/EC Regional Roma Survey 2011.

Note: the sample includes 11,609 respondents with 8,285 Roma and 3,324 non-Roma. Significance levels are $1 \%(* * *), 5 \%$ $\left({ }^{* *}\right)$ and $10 \%(*)$, respectively. 
Table 6. Self-assessed discrimination and emigration intention (marginal effects from Probit models)

\begin{tabular}{|c|c|c|c|}
\hline Variables & (1) All & (2) All & (3) Roma \\
\hline \multicolumn{4}{|l|}{ Panel A. All respondents } \\
\hline Roma & $\begin{array}{l}0.043^{* * *} \\
(3.72)\end{array}$ & $\begin{array}{l}0.023^{*} \\
(1.90)\end{array}$ & \\
\hline Any form of discrimination & & $\begin{array}{l}0.103 * * * \\
(10.98)\end{array}$ & $\begin{array}{l}0.107^{* * *} \\
(10.25)\end{array}$ \\
\hline Other covariates & YES & YES & YES \\
\hline Number of observations & 11,609 & 11,609 & 8,285 \\
\hline Log likelihood & $-5,850.9$ & $-5,791.9$ & $-4,276.5$ \\
\hline \multicolumn{4}{|l|}{ Panel B. All respondents } \\
\hline Roma & $\begin{array}{l}0.043^{* * *} \\
(3.72)\end{array}$ & $\begin{array}{l}0.018 \\
(1.46)\end{array}$ & \\
\hline Discrimination because of ethnicity & & $\begin{array}{l}0.111^{* * *} \\
(11.28)\end{array}$ & $\begin{array}{l}0.111^{* * *} \\
(10.49)\end{array}$ \\
\hline Other covariates & YES & YES & YES \\
\hline Number of observations & 11,609 & 11,609 & 8,285 \\
\hline Log likelihood & $-5,850.9$ & $-5,788.4$ & $-4,274.1$ \\
\hline \multicolumn{4}{|c|}{ Panel C. Respondents having looked for paid work } \\
\hline Roma & $\begin{array}{l}0.042^{* *} \\
(2.15)\end{array}$ & $\begin{array}{l}0.016 \\
(0.78)\end{array}$ & \\
\hline Discrimination because of ethnicity & & $\begin{array}{l}0.102 * * * \\
(6.52)\end{array}$ & $\begin{array}{l}0.107^{* * *} \\
(6.41)\end{array}$ \\
\hline Discrimination because of other reasons & & $\begin{array}{l}0.018 \\
(0.85)\end{array}$ & $\begin{array}{l}0.018 \\
(0.75)\end{array}$ \\
\hline Other covariates & YES & YES & YES \\
\hline Number of observations & 5,092 & 5,092 & 3,959 \\
\hline Log likelihood & $-2,848.9$ & $-2,824.2$ & $-2,219.0$ \\
\hline \multicolumn{4}{|l|}{ Panel D. Respondents having a job } \\
\hline Roma & $\begin{array}{l}0.052^{* * *} \\
(2.86)\end{array}$ & $\begin{array}{l}0.031^{*} \\
(1.67)\end{array}$ & \\
\hline Discrimination because of ethnicity & & $\begin{array}{l}0.133^{* * *} \\
(5.85)\end{array}$ & $\begin{array}{l}0.152^{* * *} \\
(5.89)\end{array}$ \\
\hline Discrimination because of other reasons & & $\begin{array}{l}-0.030 \\
(-1.00)\end{array}$ & $\begin{array}{l}-0.059 \\
(-1.57)\end{array}$ \\
\hline Other covariates & YES & YES & YES \\
\hline Number of observations & 3,910 & 3,910 & 2,330 \\
\hline Log likelihood & $-1,979.8$ & $-1,961.8$ & $-1,247.5$ \\
\hline
\end{tabular}

Source: authors' calculations, UNDP/WB/EC Regional Roma Survey 2011.

Note: marginal effects from Probit models, with robust standard errors. Each regression includes the various control variables used in Table 4 . Significance levels are $1 \%\left({ }^{* * *}\right), 5 \%(* *)$ and $10 \%(*)$, respectively. 
Table 7. Discrimination and emigration intention among Roma (endogeneity-corrected marginal effects)

\begin{tabular}{lccc}
\hline Variables & $\begin{array}{l}(1) \text { Linear prob. } \\
\text { model }\end{array}$ & $\begin{array}{l}(2) \text { Bivariate } \\
\text { Probit }\end{array}$ & $\begin{array}{l}\text { (3) Special } \\
\text { regressor }\end{array}$ \\
\hline Panel A. Instrument = proportion of Roma discriminated against at the country-municipality level & \\
Ethnic discrimination & $0.176^{* * *}$ & $0.165^{* * *}$ & $0.062^{* *}$ \\
& $(5.41)$ & $(5.01)$ & $(1.98)$ \\
Other covariates & YES & YES & YES \\
Number of observations & 8,285 & 8,285 & 8,203 \\
Panel B. Instrument = proportion of Roma discriminated against at the country-municipality-gender level \\
Any form of discrimination & 0.144 & $0.132^{* * *}$ & $0.082^{* *}$ \\
& $(4.04)$ & $(3.37)$ & $(2.55)$ \\
Other covariates & YES & YES & YES \\
Number of observations & 8,285 & 8,285 & 8,203 \\
\hline
\end{tabular}

Source: authors' calculations, UNDP/WB/EC Regional Roma Survey 2011

Note: marginal estimates are obtained from linear probability models with instrumental variable (column 1), bivariate Probit (column 2) and special regressor estimator (column 3). Each model includes the set of covariates reported in Table 4. Standard errors are bootstrapped with 250 replications for the bivariate Probit and special regressor estimators. Significance levels are $1 \%(* * *), 5 \%(* *)$ and $10 \%(*)$, respectively. 
Figure 1. Proportion of respondents with at least a secondary school education, by ethnicity and country

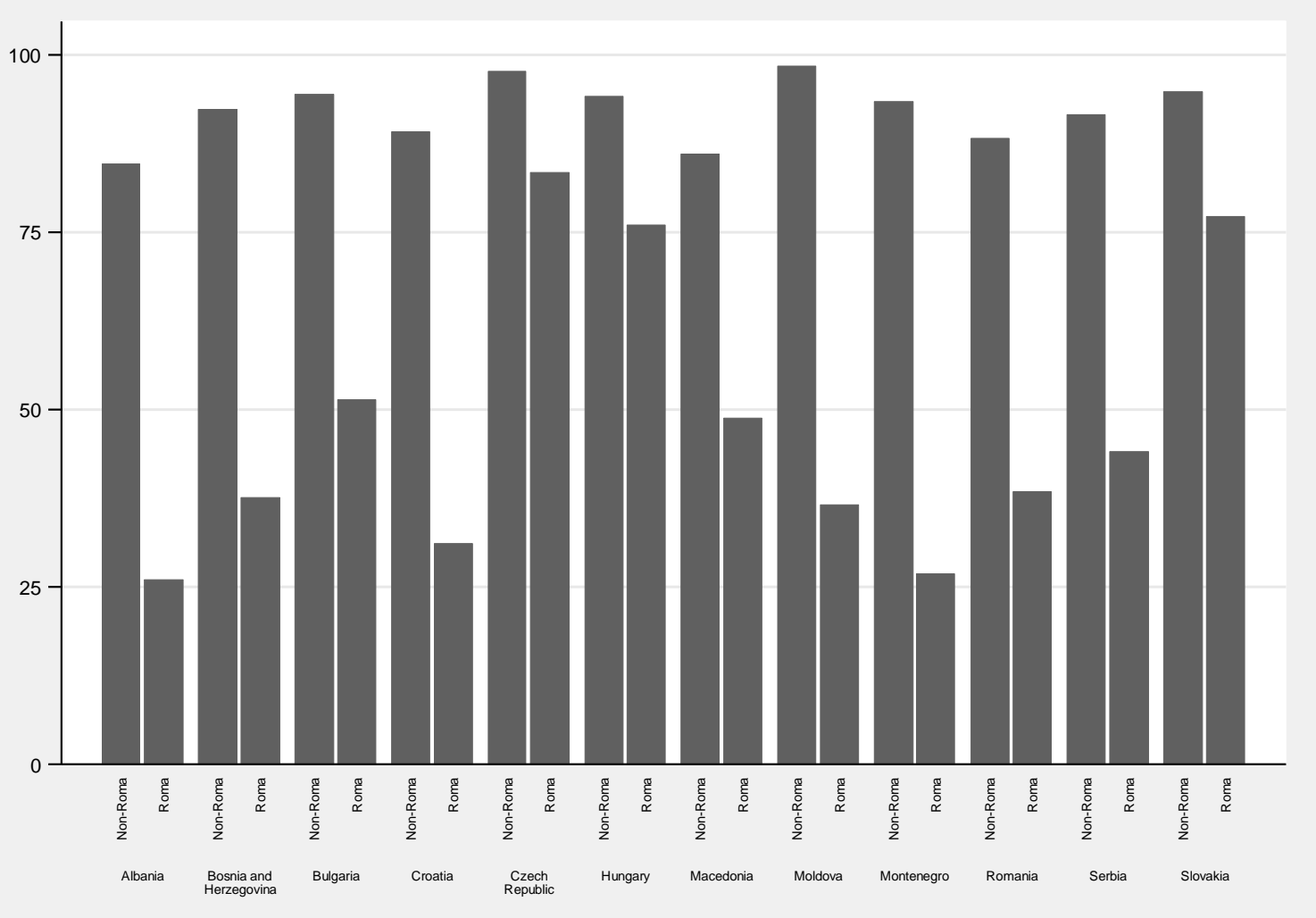

Source: authors' calculations, UNDP/WB/EC Regional Roma Survey 2011. 
Figure 2. Average asset index, by ethnicity and country

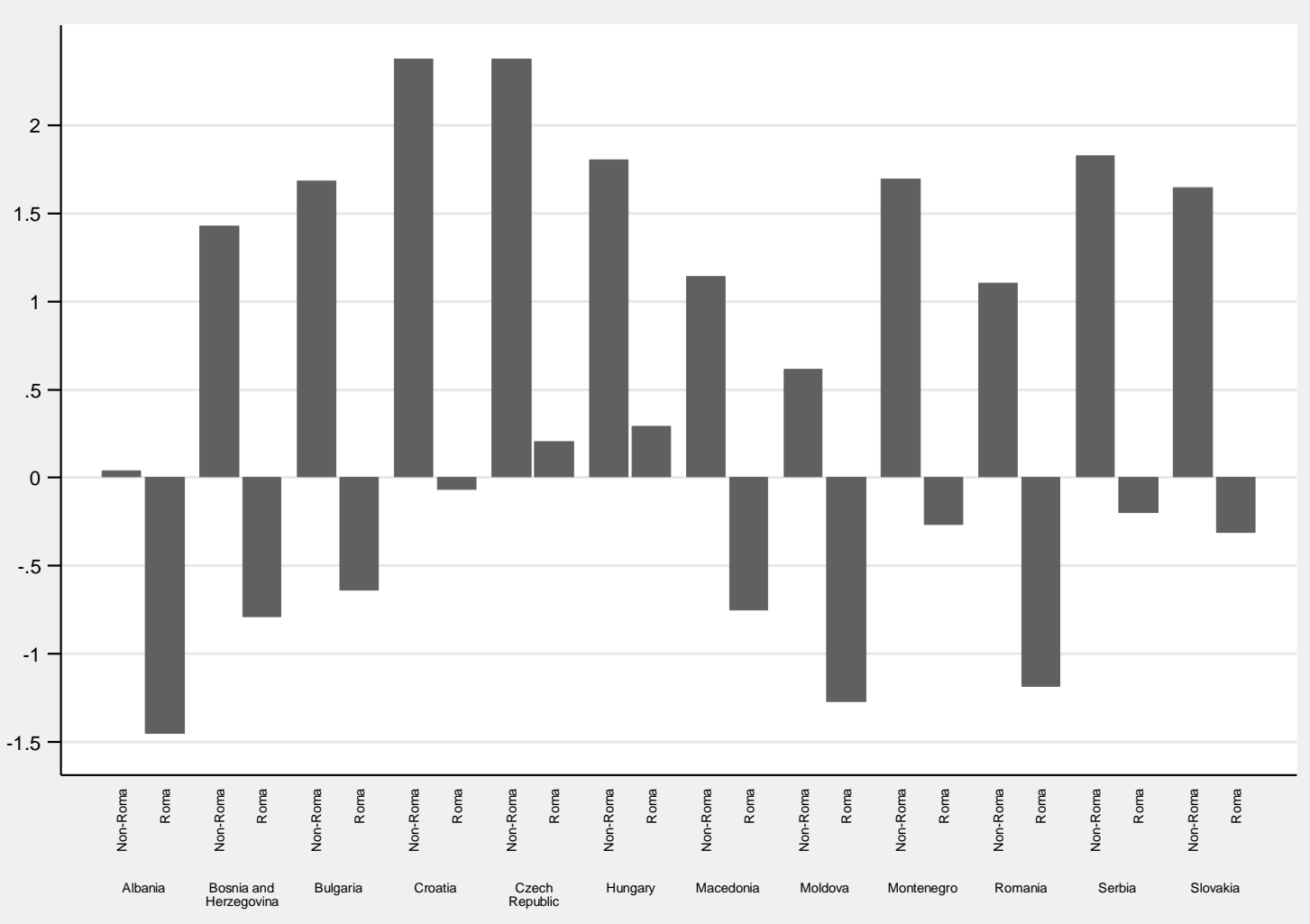

Source: authors' calculations, UNDP/WB/EC Regional Roma Survey 2011. 
Figure 3. Roma marginal effect on emigration intention, by country

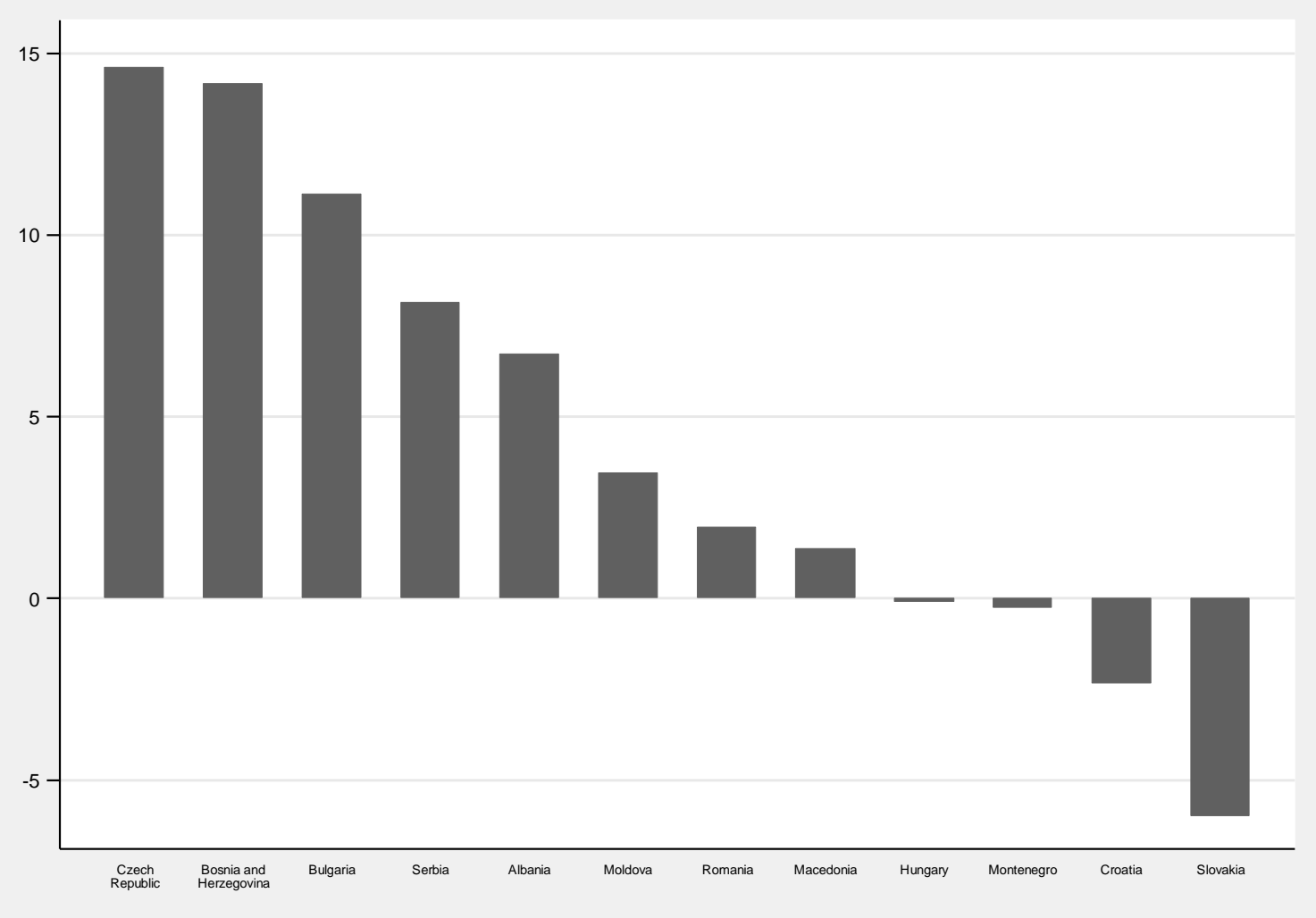

Source: authors' calculations, UNDP/WB/EC Regional Roma Survey 2011.

Note: the Roma effects are obtained by estimating specific-country regressions similar to model (2), reported in Table 4. Countries are ranked by decreasing order of importance for the Roma effect. 